\title{
VALORIZATION OF RAPESEED GRAIN BY-PRODUCTS
}

\author{
Šandor M. Kormanjoš ${ }^{1 \star}$, Sanja J. Popović ${ }^{2}$, Ljiljana M. Kostadinović1 ${ }^{1}$ Ana M. Marjanović Jeromela ${ }^{2}$, \\ Nedeljka J. Spasevski ${ }^{1}$ \\ ${ }^{1}$ University of Novi Sad, Institute of Food Technology, Bulevar cara Lazara 1, 21000 Novi Sad, Serbia
${ }^{2}$ Institute of Field and Vegetable Crops, Maksima Gorkog 30, 21000 Novi Sad, Serbia
}

\author{
*Corresponding author: \\ Phone: $+38121 / 485-3807$ \\ Fax: $+38121 / 450-725$ \\ E-mail address: sandor.kormanjos@fins.uns.ac.rs
}

\begin{abstract}
After technological processing of rapeseed significant amounts of useful and useless waste products stand out. The aim of the present study was to investigate the chemical composition, content of glucosinolates, microbiological safety, and presence of mycotoxins and heavy element contents of useful rapeseed by-products which are intended for animal nutrition. Feed components as well as complete mixtures for animal feed must be safe and in accordance with the requirements of the current national regulation. The investigated useful by-products contained significant amounts of proteins $(21.80 \%)$ and fat $(33.78 \%)$. As a part of the research, extrusion of the mixture containing rapeseed by-products and maize in the ratio of $50: 50 \%$ was performed. The process of extrusion was carried out at $130{ }^{\circ} \mathrm{C}$. Based on the obtained results it was noticed that the investigated extruded mixture is a convenient protein-energy supplement suitable for animal feed production with significantly reduced glucosinolate content (from 10.30 to $7.82 \mu \mathrm{mol} / \mathrm{g}$ ). It was also observed that the extrusion of feed mixture led to the reduction of the number of microorganisms which ensures safe feedstuff for animal feed production.
\end{abstract}

Key words: glucosinolate, feed, nutrition, by-product, rapeseed

\section{INTRODUCTION}

Worldwide, as well in Serbia, beside soybean cultivation, emphasis is given to cultivation of rapeseed (Brassica sp.). The largest producers are the European Union countries, Canada, USA, Australia, China and India (Kole et al., 2012). This oilseed crop of extreme protein-energy potential, rich in nutritionally valuable components such as protein and oil, is also characterized by the presence of antinutrients, such as erucic acid and glucosinolates.

In the production of rapeseed, technological process after harvesting of rapeseed includes the process of cleaning before storage. After combine harvesting, cleaning of rapeseed impurities, as well of broken and immature grains that do not match the quality of seed grain is done. During the process of cleaning useful and useless waste stands out. Useful waste contains broken, incomplete and immature rapeseed grain, while useless waste make parts of the stem plants, organic and inorganic impurities, rotten grains and other. Finally, it is assumed that useful by-products from the processing of rapeseed are potential protein-energy crop plant source that could be used in animal nutrition.

Extrusion is a heat process used to improve the nutritional, hygiene, physicochemical, sensory properties, as well to inactivate present thermo labile antinutrients. Glucosinolates, which include more than a hundred forms of organic anions 
containing sulfur with $\beta$-D- thioglucose unit, present the dominant antinutrients of rapeseed, which are present in both, rapeseed meal after oil extraction (Brown et al., 1991) and in the full fat feedstuffs from rapeseed (Sakač et al., 2004). Numerous studies deal with partial thermolability of glucosinolates, or with the possibility of complete inactivation of myrosinase during the process of dry extrusion (Smithard and Eyre 1986; Fenwick et al., 1983). Myrosinase represents the enzyme that catalyzes the hydrolysis of glucosinolates, with the formation of a series of toxic compounds, as well as of certain degradation of phenolic compounds by applying thermal treatment.

In our country, one of the most used processes in animal feed production is exactly extrusion process. It is used in order to partially reduce the total content of glucosinolates and total phenols present in different feedstuffs in order to obtain protein-energy nutrients with high nutritive value.

The aim of the present study was the investigation of the quality of rapeseed byproducts which remain after cleaning of rapeseed impurities, as well of broken and immature grains, and feed mixture based on maize and rapeseed by-products, and thus the possibility of its use for incorporation in animal feed. Moreover, application of adequate technological method for treating the mixture of maize and useful rapeseed by-products in order to save proteins to the greatest extent possible was also the goal of the study.

\section{MATERIALS AND METHODS}

The samples were analyzed for moisture content (AOAC 934.01), crude protein content (AOAC 978.04) and crude fiber content (AOAC 978.10). Additionally, rapeseed by-products were analyzed to crude ash (AOAC 942.05) and crude fat content (AOAC 920.39).

Glucosinolate content of rapeseed by-products was determined by the method MSZ-08-1908 (1989).

The content of aflatoxins $(\mathrm{B} 1+\mathrm{B} 2+\mathrm{G} 1+\mathrm{G} 2)$ was determined by ELISA test using a kit Aflatoxin Veratox 8031 High Sensitivity
Test. The content of zearalenone, ochratoxin and deoxynivalenol (DON) was determined by ELISA method, FINSLab-5.43M-016, FINSLab-5.4-3M-015 i FINSLab5.4-3M-018.

Determination of $\mathrm{As}, \mathrm{Pb}$ and $\mathrm{Cd}$ (Atomic absorption spectroscopy - AAS method), was examined by the method FINSLab5.4-3M-004/13. Determination of total mercury $(\mathrm{Hg})$ content by an automatic mercury analyzer - AMA 254 (AAS method), was defined by FINSLab-5.4-3M-005 method.

The total number of bacteria was determined by the method SRPS EN ISO 4833:2008 and the total number of yeasts and molds using EN ISO 21527 -2:2008 method. Coagulase positive staphylococci were determined by the method EN ISO 6881-1:2008, while Clostridium perfringens were examined by the method SRPS EN ISO 7937:2008. Salmonella spp. was investigated by the method SRPS EN ISO 6579:2008.

\section{Extrusion}

As a part of the research, extrusion of mixture of the maize and rapeseed by-products in the ratio of $50: 50 \%$ was performed. Mixture was prepared in a doubleshaft pedal mixer Muyang SLHSJ0.2A (Muyang Co., Yangzhou, PR China), after grinding raw materials in a hammer mill.

The investigation on the influence of thermal treatment on the mixture of maize and useful rapeseed by-products was performed in the pilot plant at the Institute of Food Technology in Novi Sad on an extruder manufactured by Amandus Kahl from Hamburg. The extruder has a capacity of $100 \mathrm{~kg} / \mathrm{h}$. Extrusion was conducted at $130{ }^{\circ} \mathrm{C}$.

\section{Data analysis}

The one-way ANOVA analysis and t-test were performed to assess data differences between various treatments using Statistica software version 12 (Statistica, 2013). The data means were considered different at $\mathrm{P}<0.05$.

\section{RESULTS AND DISCUSSION}

Results of chemical profile and glucosinolate content of maize and rapeseed byproducts are shown in Table 1. 
The investigated rapeseed by-products contained significant amounts of proteins $(21.80 \%)$ and fat $(33.78 \%)$ presenting in this way a convenient protein-energy supplement suitable for animal feed production.

The data on heavy element contents of the maize and rapeseed by-products is shown in Table 2.

The obtained results showed that the contents of $\mathrm{As}, \mathrm{Pb}, \mathrm{Cd}$ and $\mathrm{Hg}$ in maize and rapeseed by-products were within the limits allowed by the requirements of the current national regulation (Pravilnik, 2010) which means that the investigated maize and by-products are safe supplements for animal feed production regarding the heavy metal contents.

The mycotoxin contents in maize and useful by-products obtained by rapeseed processing are presented in Table 3.

Based on the mycotoxin contents in the tested by-products, as well in maize, it was concluded that the obtained samples meet the requirements of the current national regulation (Pravilnik, 2010). Results on chemical profile and glucosinolate content of non-extruded and extruded mixture of maize and by-products obtained by rapeseed processing are shown in Table 4.

\section{Table 1.}

Chemical composition and glucosinolate content of maize and by-products obtained by rapeseed processing

\begin{tabular}{lcc} 
Quality parameters & By-products & Maize \\
\hline Moisture content $(\%)$ & 6.74 & 11.04 \\
Crude protein $(\%)$ & 21.80 & 6.74 \\
Crude fat $(\%)$ & 33.78 & 4.61 \\
Ash $(\%)$ & 3.91 & 1.05 \\
Crude celullose $(\%)$ & 23.71 & 2.18 \\
Glucosinolate $(\mu \mathrm{mol} / \mathrm{g})$ & 22.58 & - \\
\hline
\end{tabular}

Table 2.

The content of heavy elements in maize and rapeseed by-products

\begin{tabular}{lcc}
\hline Metal & By-products & Maize \\
\hline $\mathrm{As}, \mathrm{mg} / \mathrm{kg}$ & $<1$ & $<0.5$ \\
$\mathrm{~Pb}, \mathrm{mg} / \mathrm{kg}$ & $<1$ & $<0.2$ \\
$\mathrm{Cd}, \mathrm{mg} / \mathrm{kg}$ & $<0.1$ & $<0.1$ \\
$\mathrm{Hg}, \mathrm{mg} / \mathrm{kg}$ & 0.00125 & $<0.001$ \\
\hline
\end{tabular}

Table 3.

Mycotoxin contents of maize and useful by-products obtained by rapeseed processing

\begin{tabular}{lcc}
\hline Mycotoxins & By-products & Maize \\
\hline Aflatoxins $(\mathrm{B} 1+\mathrm{B} 2+\mathrm{G} 1+\mathrm{G} 2), \mathrm{mg} / \mathrm{kg}$ & $<0.005$ & $<0.005$ \\
DON, $\mathrm{mg} / \mathrm{kg}$ & - & $3.36 \pm 1.02$ \\
Ochratoxin, $\mathrm{mg} / \mathrm{kg}$ & - & $<0.002$ \\
Zearalenone, $\mathrm{mg} / \mathrm{kg}$ & - & $0.160 \pm 0.040$ \\
\hline
\end{tabular}

Table 4.

Chemical composition and glucosinolate content of non-extruded and extruded mixture of maize and by-products obtained by rapeseed processing

\begin{tabular}{lccccc} 
Quality parameters & \multicolumn{2}{c}{ Non-extruded mixture } & \multicolumn{2}{c}{ Extruded mixture } & \multirow{2}{*}{ SEM } \\
\cline { 2 - 5 } & In sample & D.M. $^{*}$ & In sample & D.M. ${ }^{*}$ & \\
\hline Moisture content (\%) & $8.71^{\mathrm{a}}$ & - & $5.57^{\mathrm{b}}$ & - & 0.20 \\
Crude protein (\%) & $15.33^{\mathrm{a}}$ & $16.78^{\mathrm{a}}$ & $15.66^{\mathrm{a}}$ & $16.58^{\mathrm{a}}$ & 0.42 \\
Crude fat (\%) & $18.88^{\mathrm{a}}$ & $20.68^{\mathrm{a}}$ & $20.42^{\mathrm{a}}$ & $21.62^{\mathrm{a}}$ & 0.65 \\
Ash (\%) & $2.54^{\mathrm{a}}$ & $2.78^{\mathrm{a}}$ & $2.57^{\mathrm{a}}$ & $2.72^{\mathrm{a}}$ & 0.09 \\
Crude celullose (\%) & $13.50^{\mathrm{a}}$ & $14.79^{\mathrm{a}}$ & $13.36^{\mathrm{a}}$ & $14.15^{\mathrm{a}}$ & 0.35 \\
Glucosinolate $(\mu \mathrm{mol} / \mathrm{g})$ & $10.30^{\mathrm{a}}$ & $11.28^{\mathrm{a}}$ & $7.82^{\mathrm{b}}$ & $8.28^{\mathrm{b}}$ & 0.40 \\
\hline
\end{tabular}

${ }^{\star} D$.M. - dry matter basis; SEM - standard error of the means $(n=3)$

${ }^{a-b}$ Values with different letter indexed in the same row are statistically significantly different $(P<0.05)$ 
Table 5.

Microorganism count of non-extruded and extruded mixture of maize and by-products obtained by rapeseed processing

\begin{tabular}{lcc}
\hline Microorganism & Non extruded mixture & Extruded mixture \\
\hline TVCYM (cfu/g) & 14000 & $<100$ \\
TVAC (cfu/g) & 2100 & $<10$ \\
C.perfringens (cfu/g) & $<10$ & $<10$ \\
Coagulase-positive staphylococci (cfu/g) & $<100$ & $<100$ \\
Salmonella spp & not detected in $50 \mathrm{~g}$ & not detected in $50 \mathrm{~g}$ \\
\hline cfu- colony forming units; TVCYM - total viable count yeasts and moulds; TVAC- total viable aerobic count
\end{tabular}

Based on the conducted investigation on the potential application of dry extrusion processing of mixture consisted from waste products of rapeseed in combination with maize, it can be noticed that the feed mixture prepared in this manner has showed satisfying nutritional and chemical profile with a significant reduction in the content of glucosinolates, which is approximately $24.08 \%$ (from 10.30 to 7.82 $\mathrm{mmol} / \mathrm{g}$ ). Reductions of total glucosinolate content $(19-23 \%)$ was recorded by Smithard and Eyre (1986), applying the procedure of dry extrusion $\left(135^{\circ} \mathrm{C}\right)$ on a mixture of rapeseed and barley as well on mixture of rapeseed and sunflower meal, while the application of dry extrusion on rapeseed achieved reduction of glucosinolates content of $19 \%$ (Aumaitre et al., 1989).

However, based on the fact that the heat treatment was used to improve the nutritional, hygienic, physical, chemical and other characteristics of the treated material, and, besides the inactivation of the thermo labile antinutrients, to increase the nutritional value of nutrients, enhance the sensory properties and provides microbiological safety of the final product (Verheul, 1997), determination of the application of extrusion is more than justified by the concept of the production of proteinenergy feed based on rapeseed. Sakač et al. (2006) investigated the impact of extrusion on glucosinolates content and total phenols of rapeseed. The process of dry extrusion of mixture of rapeseed and agricultural products is already known as one of the most common ways of thermal processing of oil crops, which results in the production of high-quality protein-energy nutrients (Sakač et al., 2004; Filipović et al., 2004; Filipović et al., 2005; Font et al., 2005). This orientation is widely ap- plied since the extrusion of rapeseed, due to high crude fat, prevents adequate heating of the material and leads to the appearance of oily extrudate susceptible to lipid oxidation (Smithard and Eyre, 1986). On the other side, dry extrusion of mixture of rapeseed and agricultural products results in nutrients of greater sustainability, suitable for storage and composing with other nutrients (Eyre and Smithard, 1984).

The microorganism count of non-extruded and extruded mixture of maize and byproducts obtained by rapeseed processing is shown in Table 5.

Based on the content of microorganisms in the extruded mixture of maize and by-products obtained by rapeseed processing (Table 5), it can be concluded that the investigated sample met the requirements of the current national regulation (Pravilnik, 2010).

Moreover, during the extrusion processing of the mixture, reduction in the number of microorganisms was observed which provides hygienic safety of the extruded product, and is very important in terms of storage and preservation of extruded material (Kormanjoš et al., 2007; Kormanjoš et al., 2008; Kormanjoš et al., 2012a; Kormanjoš et al., 2012b). The extrusion processing can be of great importance from the standpoint of reducing the number of microorganisms despite the relatively low temperature applied in this treatment $\left(130{ }^{\circ} \mathrm{C}\right)$, within a very short time (6$10 \mathrm{~s}$ ), but at very high pressure (from 30 to 40 bar).

\section{CONCLUSIONS}

Regarding the obtained results it could be concluded that rapeseed by-products are protein-energy nutrients appropriate for animal feed production. Regarding the re- 
sults on mycotoxin and heavy element contents in the rapeseed by-products, it was found that the obtained feed component can be safely used in animal feed production. Furthermore, microbiological profile, as well as chemical composition and glucosinolate content in the extruded mixture of maize and rapeseed by-products, indicated that the investigated mixture can be used in animal nutrition.

\section{ACKNOWLEDGEMENTS}

The paper is a part of the research work on the project III46012 financed by the Ministry of Education, Science and Technological Development of the Republic of Serbia.

\section{REFERENCES}

1. AOAC (1998). Official Methods of Analysis of AOAC International $16^{\text {th }}$ Edition, AOAC International, Gaithersburg, MD, USA, Official Methods 920.39, 934.01, 942.05, 978.04, 978.10.

2. Aumaitre, A., Bourdon, D., Peiniau, J., Bengala Freire, J. (1989). Effect of graded levels of raw and processed rapeseed on feed digestibility and nutrient utilization in young pigs. Animal Feed Science and Technology, 24 (3-4), 275287.

3. Brown, P.D., Morra, M.J., McCaffrey, J.P., Auld, D.L., Williams L. (1991). Allelochemicals produced during glucosinolate degradation in soil. Journal of Chemical Ecology, 17 (10), 20212034.

4. EN ISO 21527 (2008). Microbiology of food and animal feeding stuffs - Horizontal method for the enumeration of yeasts and moulds - Part 2: Colony count technique in products with water activity less than or equal to 0.95 .

5. EN ISO 6888-1 (2008). Microbiology of food and animal feeding stuffs- Horizontal method for the enumeration of coagulase positive staphylococci (Staphylococcus aureus and other species) - Part: 1: Technique using Baird Parker agar medium.

6. Eyre, M.D., Smithard, R.R. (1984). The effects of processing of rapeseed upon its anti-thyroid activity and the utilisation of its protein. Journal of the Science of Food and Agriculture, 35 (8), 827-832.

7. Fenwick, G.R., Heaney, R.K., Mullin, W.J. (1983). Glucosinolates and their breakdown products in food and food plants. C RC Critical Reviews in Food Science and Nutrition, 18 (3), 123-201.

8. Filipović, S., Sakač, M., Borojević, Č., Ristić, M., Kormanjoš, Š. (2004). Tehnološki postupak ekstrudiranja uljane repice sa primarnim poljoprivrednim proizvodima. 45. Savetovanje Industrije ulja "Proizvodnja i prerada uljarica", Petrovac na moru, Montenegro, Zbornik radova, pp. 141-146.
9. Filipović, S., Sakač, M., Ristić, M., Kormanjoš, Š. (2005). Heat treatments for cereals and oilseed meals processing. $11^{\text {th }}$ International Feed Technology Symposium "Quality Assurance", Vrnjačka Banja, Serbia, Proceedings, pp. 259-272.

10. Font, R., del Río-Celestino, M., Cartea, E., de Haro-Bailón, A. (2005). Quantification of glucosinolates in leaves of rape (Brassica napus ssp. pabularia) by near-infrared spectroscopy. Phytochemistry, 66 (2), 175-185.

11. Kole, C., Joshi, C.P., Shonnard, D.R. (2012). Handbook of Bioenergy Crop Plants, CRC Press, Los Angeles.

12. Kormanjoš, Š., Filipović, S., Čabarkapa, I., Radović, V., Filipović, J., Hristov, N. (2012b). Quality of wheat by-producst aimed for animal feeding. XV International Feed Technology Symposium „Feed-to Food“/ COST- „Feed for Health" Joint Workshop, Novi Sad, Serbia, Proceedings, pp. 246-252.

13. Kormanjoš, Š., Filipović, S., Plavšić, Dragana, Lazarević, R., Živančev, D., Filipović, J. (2008). Uticaj ekstrudiranja na higijensku ispravnost kukuruza. Časopis za procesnu tehniku $i$ energetiku u poljoprivredi, 12 (4), 222-224.

14. Kormanjoš, Š., Filipović, S., Radović, V., Plavšić, D., Filipović, J., Filipović, V. (2012a). The importance of broken corn kernels extrusion. 6th Central European Congress on Food (CEFood2012), Novi Sad, Serbia, Proceedings, pp.1539-1542.

15. Kormanjoš, Š., Filipović, S., Sakač, M., Ristić, M., Filipović, J., Plavšić, D. (2007). Uticaj ekstrudiranja na higijensku ispravnost oplemenjenog kukuruznog stočnog brašna. I International Congress Food Technology, Quality and Safety and XII International Symposium Feed Technology, Novi Sad, Serbia, Proceedings, pp.152-156.

16. MSZ-08-1908 (1989). Determination of the glucosinolate content of rapeseeds and rapeseed meals.

17. Pravilnik (2010). Pravilnik o kvalitetu hrane za životinje. Službeni glasnik RS, 4/2010, 113/2012, 27/2014 i 80/2015.

18. Sakač, M., Filipović, S., Borojević, Č., Ristić, M., Kormanjoš, Š. (2004). Uticaj ekstrudiranja na sadržaj ukupnih glukozinolata uljane repice. 45. Savetovanje industrije ulja "Proizvodnja i prerada uljarica", Petrovac na moru, Serbia and Montenegro, Proceedings, pp. 133-139.

19. Sakač, M., Filipović, S., Borojević, Č., Ristić, M., Kormanjoš, Š. (2006). Uticaj ekstrudiranja na sadržaj ukupnih glukozinolata i ukupnih fenola uljane repice. XI Savetovanje o biotehnologiji, Čačak, Serbia, Proceedings, pp. 547-556.

20. Smithard, R.R., Eyre, M.D. (1986). The effects of dry extrusion of rapeseed with other feedstuffs upon its nutritional value and anti-thyroid activity. Journal of the Science of Food and Agriculture, 37 (2), 136-140.

21. SRPS EN ISO 4833 (2008). Microbiology of food and animal feeding stuffs - Horizontal method for the enumeration of microorganisms. Colony-count technique at $30^{\circ} \mathrm{C}$. 
22. SRPS EN ISO 6579 (2008). Microbiology of food and animal feeding stuffs. Horizontal method for the detection of Salmonella spp.

23. SRPS EN ISO 7937 (2008). Microbiology of food and animal feeding stuffs - Horizontal me- thod for the enumeration of Clostridium perfringens - Colony-count technique.

24. Verheul, J.A. (1997). Sallmonela-free production. Cebeco consulting engineers information, $7(11), 7-8$.

\title{
ВАЛОРИЗАЦИЈА СПОРЕДНИХ ПРОИЗВОДА ИЗ ДОРАДЕ СЕМЕНСКЕ УЉАНЕ РЕПИЦЕ
}

\author{
Шандор М. Кормањош ${ }^{1 *}$, Сања Ј. Поповић ${ }^{1}$, љиљана М. Костадиновић ${ }^{1}$, Ана М. Марјановић \\ Јеромела ${ }^{2}$, Недељка Ј. Спасевски ${ }^{1}$ \\ ${ }^{1}$ Универзитет у Новом Саду, Научни институт за прехрамбене технологије у Новом Саду, \\ 21000 Нови Сад, Булевар цара Лазара бр. 1, Србија \\ ${ }^{2}$ Институт за ратарство и повртарство, Максима Горког 30, 21000 Нови Сад, Србија
}

Сажетак: У технолошком поступку прераде семенске уљане репице издваја се значајна количина отпадних продуката. Циљ истраживања био је да се испита хемијски састав, садржај глукозинолата, микробиолошка исправност, присуство микотоксина и тешких метала у нуспроизводима који се добијају при доради семенске уљане репице, намењених производњи хране за животиње. Потпуне смеше за исхрану животиња као и хранива морају бити хигијенски исправне и удовољити захтевима важећег Правилника о квалитету хране за животиње. На основу испитивања поменутих параметара, установљено је да испитивани споредни производи садрже значајну количину протеина $(21,80 \%)$ и масти $(33,78 \%)$. У оквиру истраживања извршено је екструдирање споредног производа из дораде семенске уљане репице са кукурузом у односу 50:50\%. Екструдирање смеше примеса из дораде семенске уљане репице и кукуруза је спроведено на температури од $130{ }^{\circ} \mathrm{C}$. Добијено је храниво задовољавајућег нутритивно-хемијског профила, уз значајну редукцију садржаја глукозинолата за $24,08 \%$ (са 10,30 на $7,82 \mu \mathrm{mol} / \mathrm{g}$ ). На основу изведених испитивања, установљено је да процесом екструдирања хранива долази до смањења броја микроорганизама чиме се обезбеђује хигијенска исправност екструдата.

Кључне речи: глукозинолати, исхрана животиња, споредни производ, уљана репица

Received: 3 December 2015

Accepted: 29 January 2016 